\title{
PENANGKAPAN IDE BACAAN \\ SISWA SMP LABSCHOOL UNESA KETINTANG SURABAYA PASCA GERAKAN LITERASI
}

\author{
Muhammad Thamrin Hidayat, Suharmono Kasiyun \\ Universitas Nahdlatul Ulama Surabaya \\ e-mail: pmksthamrin@gmail.com
}

\begin{abstract}
Abstrak: Pencanangan Surabaya Kota Literasi telah dilakukan Walikota Surabaya pada 2 Mei 2014. Pencanangan Kota Literasi berlanjut pada setiap sekolah-sekolah yang ada di Surabaya. Pengejawatahannya kegiatan literasi dilakukan limabelas menit setiap pagi sebelum pelajaran dimulai. Untuk mengetahui adakah dampak dari pelaksanaan literasi terhadap penangkapan ide bacaan siswa dan bagaimanakah tanggapan siswa terhadap pelaksanaan literasi tersebut, diadakan penelitian untuk melihat tingkat penangkapan ide bacaan dengan menggunakan metode bacaan rumpang, sedangkan tanggapan siswa terhadapat pelaksanaan dengan menggunakan wawancara maupun angket. Hasil penelitian ini menunjukkan bahwa pelaksanaan literasi menghasilkan tingkat ide bacaan para siswa sangat baik dan tanggapan siswa tentang pelaksanaan literasi sangat positif. Kekurangan adalah bahan bacaan yang kurang bervariasi.
\end{abstract}

Kata Kunci: Literasi, penangkapan ide bacaan

\begin{abstract}
The launching of the Surabaya City of Literacy was carried out by the Mayor of Surabaya on May 2, 2014. The launching of the City of Literacy continued in every school in Surabaya. Management of literacy activities is carried out fifteen minutes every morning before the lesson begins. To find out whether there is an impact of literacy on the capture of student reading ideas and how students respond to literacy implementation, a study was conducted to look at the level of capture of reading ideas by using the hitching reading method, while student responses to the implementation using interviews and questionnaires. The results of this study indicate that the implementation of literacy produced a very good level of students reading ideas and student responses to literacy implementation were very positive. Disadvantages are less varied reading material,
\end{abstract}

Keyword: Literacy, Arrest Reading Ideas

\section{PENDAHULUAN}

Di dunia pendidikan dalam proses belajar mengajar tidak terlepas dari buku. Di dalam buku terdapat beberapa tulisan yang berguna untuk menyampaikan hal yang berhubungan berita, cerita sejarah, ungkapan dari seseorang dalam bentuk tulisan. Untuk mengetahui apa isi dari bacaan yang tertulis di dalam buku tersebut seseorang harus membacanya.

Pengertian membaca sebagai sebuah istilah sangat beraneka ragam. Membaca dalam arti yang sederhana adalah menyuarakan huruf atau deretan huruf yang berupa kata atau kalimat. Tetapi membaca tidak harus menyuarakan apa 
yang dibaca, tetapi cukup memperhatikan bacaan dan paham serta memaknai bacaan dalam hati, itu sudah dikatakan membaca. Membaca adalah suatu proses yang dilakukan serta dipergunakan oleh pembaca untuk memperoleh pesan, yang hendak disampaikan oleh penulis melalui media kata-kata/bahasa tulis (Tarigan, 1990: 7). Adapun hakikat membaca adalah melihat tulisan dan menyuarakan atau tidak bersuara (dalam hati) serta mengerti isi tulisannya (Zainuddin, 1992: 72). Membaca adalah usaha untuk mendapatkan sesuatu yang ingin diketahui, mempelajari sesuatu yang ingin dikerjakan, atau mendapat kesenangan dan pengetahuan dari suatu tulisan (Semi, 1993: 100).

Membaca dimaksudkan untuk melafalkan bunyi yang tertulis kemudian menangkap gagasan yang terkandung dalam rangkaian bunyi (Pranowo, 1996: 88). Membaca berarti melihat serta memahami isi dari apa yang tertulis (dengan melisankan atau hanya di dalam hati); mengeja atau melafalkan apa yang tertulis. Membaca bukanlah suatu proses ekafaktor, melainkan keterampilan dan kemampuan yang interaktif dan terpadu (Harjasujana, 1986: 9). Dalam komunikasi lisan, seperti yang telah dikatakan, lambang-lambang bunyi bahasa diubah menjadi lambanglambang tulisan atau huruf, dalam hal ini hurufhuruf menjadi alfabet lain (Tampubolon, 1987: 5). Membaca pada dasarnya adalah proses kognitif. Walaupun pada taraftaraf penerimaan lambang-lambang tertulis diperlukan kemampuan kemampuan motoris berupa gerakangerakan mata, kebanyakan dari kegiatankegiatan membaca sebagai proses kognitif adalah kegiatan-kegiatan pikiran atau penalaran termasuk ingatan (Tampubolon, 1990: 6).

Membaca merupakan perbuatan yang dilakukan berdasarkan kerja sama dari berbagai keterampilan, yaitu mengamati, memahami, dan memikirkan (Burhan, 1991: 91). Di dalam konteks pembelajaran, membaca dipandang sebagai suatu proses menuju pemahaman sebagai produk yang diukur. Pada proses itu terjadi peralihan informasi yang dikandung oleh lambang grafis yang mewakili kata (Semi, 1993: 99).

Tujuan membaca menurut Tarigan (1986: 9-10) adalah untuk mencari serta memperoleh informasi, mencakup isi, dan memahami isi bacaan. Makna, arti erat sekali berhubungan dengan maksud, tujuan, atau intensif kita dalam membaca. Sekolah Menengah Pertama (SMP) Labschool Unesa Ketintang Surabaya telah melakukan kegiatan literasi sejak i tahun 2016 hingga sekarang, hal ini sesuai pencanangan Kota Surabaya sebagai kota literasi pada Tanggal 2 Mei 2015. Kota Surabaya Literasi (SKL) digalakkan semua sekolah harus melaksanakannya. Sesuai instruksi tersebut SMP Labschool Unesa Ketintang Surabaya setiap pagi mengadakan baca buku selama 15 menit sebelum pelajaran berlangsung. Sudah hampir 3 tahun lebih sekolah sudah melaksanakan, tetapi belum ada evaluasi hasil kegiatan literasi tersebut. Berdasarkan masalah di atas sekolah mencoba untuk membuat penelitian expofacto dengan judul : "Penangkapan Ide Bacaan Siswa SMP Labschool Unesa Ketintang Surabaya Pasca Gerakan Literasi ” 


\section{a. Ruang Lingkup Penelitian}

Ruang lingkup penelitian dalam penelitian ini menyangkut beberapa hal:

1) Pencanangan Surabaya Kota Literasi telah dilakukan Walikota Surabaya pada 2 Mei 2014. Pada 2 s.d. 5 Maret 2015 program Tantangan Membaca Surabaya 2015.

2) Kegiatan membaca buku setiap selama lima belas menit sebelum pembelajaran dimulai.

3) Pengungkapan penangkapan ide bacaan dengan menggunakan 'cloze procedure' (bacaan rumpang)

4) 'Cloze procedure' Bacaan yang digunakan adalah cerita rakyat judul Bawang putih dan Bawang merah.

\section{b. Rumusan Masalah}

Adapun masalah penelitian ini dapat dirumuskan pertanyaan penelitian sebagai berikut:

1) Bagaimanakah aktivitas siswa saat melakukan kegiatan literasi ?

2) Bagaimanakah respon siswa saat melakukan kegiatan literasi ?

3) Bagaimanakah hasil penangkapan ide bacaan siswa setelah melakukan kegiatan literasi ?

\section{c. Tujuan Penelitian}

Adapun tujuan penelitian ini untuk mendapatkan gambaran yang jelas pengaruh pelaksanaan literasi terhadap penagkapan ide bacaan siswa.

\section{d. Hasil yang Diharapkan}

Hasil yang diharapkan adalah mendapatkan gambaran yang jelas tingkat kemaampuan penangkapan ide bacaan setelah diberi kegiatan literasi siswa SMP Labschool Unesa Ketintang
Surabaya selama lima belas menit tiap hari sebelum jam belajar.

\section{e. Manfaat Penelitian}

Dapat digunakan untuk mendukung kegiatan yang lebih luas tentang manfaat literasi. Kemampuan wacana merupakan kemampuan untuk mengetahui dan mengerti isi bacaan secara tepat dan cepat dengan cara melihat hubungan makna yang terdapat dalam bacaan. Seseorang dikatakan mampu memahami wacana apabila ia mengerti tentang kata-kata, kalimat, paragraf, dan ide-ide atau pesan yang ingin disampaikan melalui tulisannya. Konsep tingkat kemampuan ini mengacu pada konsep Penilaian Acuan Patokan (PAP) yang diungkapkan oleh Nurgiyantoro (1988: 363), yaitu penentuan batas minimal kelulusan dan pemberian nilai tertentu dapat dilakukan dengan perhitungan persentase. Tingkatan kemampuan memahami wacana adalah sebagai berikut.

1) $85 \%-100 \%$ termasuk tingkatan kemampuan baik sekali;

2) $75 \%-84 \%$ termasuk tingkat kemampuan baik;

3) $60 \%-74 \%$ termasuk tingkat kemampuan cukup;

4) $40 \%-59 \%$ termasuk tingkat kemampuan kurang;

5) $0 \%-39 \%$ termasuk tingkat kemampuan sangat kurang.

(Nurgiyantoro, 1988: 363)

Dalam kajian ini akan dijelaskan halhal yang berkaitan dengan teknik uji rumpang, yaitu pengertian uji rumpang, fungsi uji rumpang, kegunaan uji rumpang, kriteria pembuatan uji rumpang, serta keunggulan dan kelemahan uji rumpang. 
Diungkapkan oleh Hardjsudjana (1996: 115) bahwa teknik uji rumpang mula-mula diperkenalkan oleh Wilson Taylor (1953) dengan nama 'cloze procedure'. Teknik ini diilhami oleh suatu konsep dalam ilmu jiwa Gestal, yang dikenal dengan istilah 'clozure'. Konsep ini menjelaskan tentang kecenderungan manusia untuk menyempurnakan suatu pola yang tidak lengkap secara mental menjadi satu kesatuan yang utuh; kecenderungan untuk mengisi atau melengkapi sesuatu yang sesungguhnya ada, tampak dalam keadaan yang tidak utuh; melihat bagianbagian sebagai suatu keseluruhan. Seperti dijelaskan oleh Sadtono (1982: 2) istilah 'clozure' mengandung makna sebagai persepsi (penglihatan dan pengertian) yang penuh atau komplit dari gambar atau keadaan yang sebenarnya tidak sempurna. Persepsi keadaan yang sempurna itu diperoleh dengan cara tidak menghiraukan bagian yang hilang atau bagian yang tidak sempurna itu; atau dengan cara mengisi sendiri bagian yang hilang atau kurang sempurna tadi berdasarkan pengalaman yang telah lampau. Berdasarkan konsep tersebut Taylor mengembangkannya menjadi sebuah alat ukur keterbacaan wacana yang diberinya nama 'cloze procedure'. Istilah itu selanjutnya disebut sebagai 'prosedur/teknik uji rumpang', definisi yang dibuat langsung oleh Taylor (1953) selaku pencipta teknik ini.

\section{METODE PENELITIAN}

\section{a. Jenis Penelitian}

Penelitian ini merupakan penelitian ex post facto, Penelitian expost facto merupakan penelitian yang bertujuan menemukan penyebab yang memungkinkan perubahan perilaku, gejala atau fenomena yang disebabkan oleh suatu peristiwa, perilaku atau hal-hal yang menyebabkan perubahan pada variable bebas yang secara keseluruhan sudah terjadi. Penelitian ex post facto secara metodologis merupakan penelitian eksperimen yang juga menguji hipotesis tetapi tidak memberikan perlakuanperlakuan tertentu karena sesuatu sebab kurang etis untuk memberikan perlakuan atau memberikan manipulasi. Biasanya karena alasan etika manusiawi, atau gejala/peristiwa tersebut sudah terjadi dan ingin menelusuri faktor-faktor penyebabnya atau hal-hal yang mempengaruhinya. Selain penelitian ex post facto penelitian ini diskripsi kualitatif untuk menunjuang hasil dari penelitian expostfacto agar penelitian ini lebih jelas di dalam simpulan.

Dengan demikian kegiatan literasi yang dilakukan oleh SMP Labschool Unesa Ketintang selama lima belas menit setiap pagi sebelum pembelajaran dimulai apakah memiliki dampak pada peningkatan penangkapan ide bacaan siswa. Untuk mendapatkan gambaran penangkapan ide bacaan menggunakan teknik uji rumpang yang pernah dikembangkan oleh Taylor (1953) dengan nama 'cloze procedure'.

Subyek penelitian adalah siswa SMP Labschool Unesa Ketintang Surabaya kelas VII, VIII sebanyak 108 siswa. Lokasi penelitian di SMP Labschool Unesa Ketintang Surabaya di Kampus Unesa Ketintang Surabaya. Waktu penelitian Bulan Nopember 2018. Variable bebas adalah membaca buku selama lima belas menit sebelum 
pelajaran dimulai. Variabel terikat Penangkapan ide bacaan siswa.Variabel kontrol : bacaan berupa buku cerita

\section{b. Prosedur Penelitian}

Prosedur penelitian menganut prosedur penelitian ex post facto yakni yang bertujuan menemukan penyebab yang memungkinkan perubahan penangkapan ide bacaan karena adanya perlakukan siswa setiap pagi selama lima belas menit diharuskan membaca buku bacaan berupa bacaan cerita. Kemudian setelah itu berselang beberapa bulan diadakan tes menggunakan teknik uji rumpang. Hasilnya dirata-rata dan tingkat kemampuan ini mengacu pada konsep Penilaian Acuan Patokan (PAP). Tingkatan kemampuan memahami wacana adalah sebagai berikut.

1) $85 \%-100 \%$ termasuk tingkatan kemampuan baik sekali;

2) $75 \%-84 \%$ termasuk tingkat kemampuan baik;

3) $60 \%-74 \%$ termasuk tingkat kemampuan cukup;

4) $40 \%-59 \%$ termasuk tingkat kemampuan kurang;

5) $0 \%-39 \%$ termasuk tingkat kemampuan sangat kurang.

Bila digambarkan dalam diagram seperti pada Diagram 1 di bawah ini:

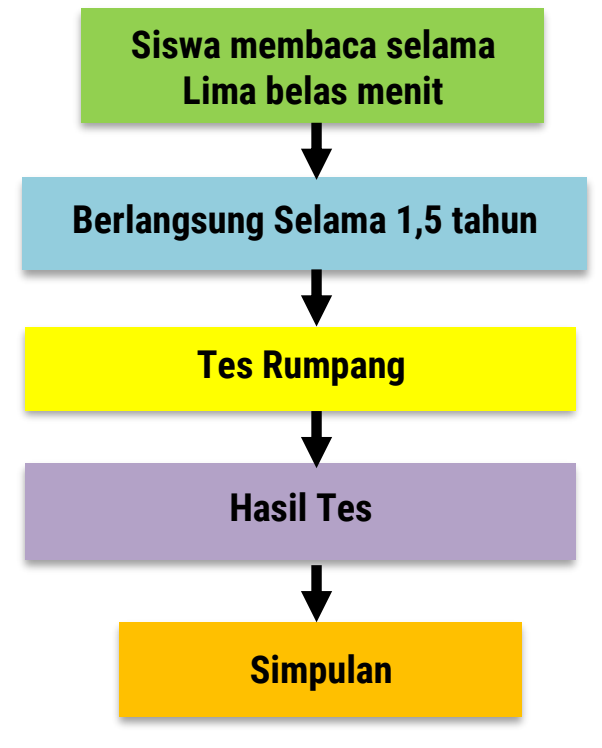

Diagram 1: Alir Penelitian

\section{HASIL PENELITIAN}

\section{a. Gambaran Pelaksanaan Literasi}

Pelakasanaan literasi ini dilakukan sudah berjalan kurang lebih 2,5 tahun. Pelaksanaannya semula dilakukan di dalam kelas masing-masing, namun pelaksanaan kurang kondosif, hal ini disebabkan pengawas siswa yang membaca di dalam kelas kadangkala guru terlambat datang atau tidak masuk ke dalam kelas. Hasilnya siswa banyak yang hanya bergurau, bercerita bahkan tidak membaca buku sama sekali. Untuk menghilangkan permasalahan tersebut, dilakukan perubahan. Membaca buku bacaan harus diluar kelas, yaitu dilakukan di selasar depan kelas masing-masing. Membaca di selasar berjalan dalam beberapa bulan dirasa juga kurang efektif. Diputuskan semua siswa membaca di halaman sekolah, ber deret deret sesuai kelas masing-masing agar siswa dapat dipantau secara langsung oleh semua guru yang hadir pagi itu. 
Hasilnya dengan membaca di halaman sekolah berdampak sangat efisien dan efektif di dalam pelaksanaan literasi. Namun kendala masih selalu ada yaitu apabila hujan turun atau setelah hujan, pelaksanaan di halaman tidak terlaksana dan dipindahkan ke dalam kelas masing-masing.

Bagi siswa yang datang terlambat, siswa dihukum untuk membersihkan halaman dari sampah-sampah daun dari pohon. Hukuman tidak selalu membersihkan halaman tetapi mereka diberitugas untuk menyusun ringkasan dari bacaan yang mereka baca. Hasil ringkasan dianalisis tentang : kebahasaan terdiri: rumusan judul, penggunaan ejaan, penggunaan tanda baca, pilihan kata, struktur kalimat, paragraf. Sedangkan tentang isi yang dnilai yaitu: kelengkapan,keruntunan, dan keterpaduan (ini menjadi laporan tersendiri). Dari pengelolaan tersebut sekarang sudah berjalan dengan baik tanpa hambatan yang berarti, dan nampaknya siswa sudah mulai menyadari kegiatan literasi yang dilakukan oleh sekolah.

\section{b. Hasil Penangkapan Ide Bacaan} adalah Tingkatan kemampuan siswa memahami wacana dengan menggunakan tes bacaan dengan menggunakan 'cloze procedure' seperti Tabel 1 sebagai berikut:

\begin{tabular}{|c|c|c|c|c|c|c|}
\hline No & Kelas & $\begin{array}{c}\text { Jumlah } \\
\text { siswa }\end{array}$ & $\begin{array}{c}\text { Nilai } \\
\text { tertinggi }\end{array}$ & $\begin{array}{c}\text { Nilai } \\
\text { terendah }\end{array}$ & $\begin{array}{c}\text { Rata- } \\
\text { rata }\end{array}$ & Ket. \\
\hline 1 & $\begin{array}{c}\text { VII } \\
\text { A }\end{array}$ & 26 & 94 & 25 & 66,9 & Cukup \\
\hline 2 & $\begin{array}{c}\text { VII } \\
\text { B }\end{array}$ & 27 & 93 & 45 & 70,28 & Cukup \\
\hline 3 & $\begin{array}{c}\text { VIII } \\
\text { A }\end{array}$ & 26 & 97 & 61 & 81,15 & Baik \\
\hline 4 & $\begin{array}{c}\text { VIII } \\
\text { B }\end{array}$ & 22 & 92 & 56 & 77,09 & Baik \\
\hline
\end{tabular}

Tabel 1 : Gambaran Penagkapan Ide Bacaan siswa

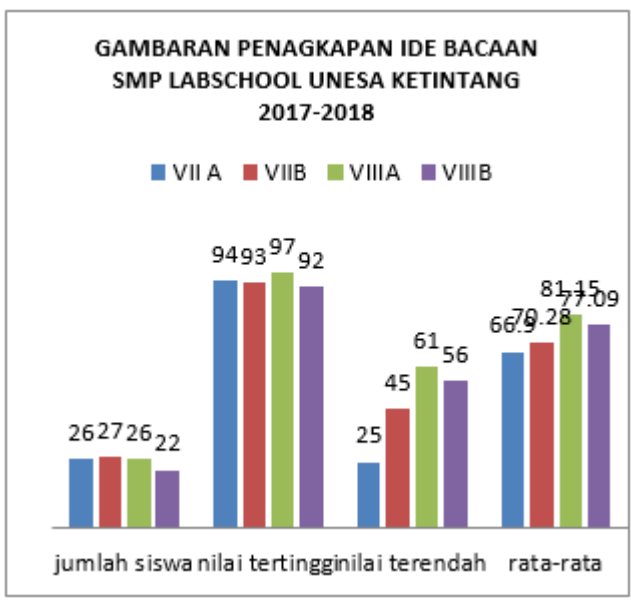

Gambar 2 : Grafik Penangkapan Ide Bacaan

\section{c. Aktivitas siswa}

Aktivitas siswa di dalam penelitian ini yang dimaksud adalah bagaimana siswa mempersiapkan bacaan sebelum mereka membaca bersama-sama di halaman sekolah dengan tenang (membaca dalam hati). Pada umumnya siswa membaca dengan sungguhsungguh, namun tidak semua yang membaca sungguh-sungguh ada pula yang masih melamun dan juga berbicara dengan teman berdekatan. Pada hari-hari tertentu pelaksaanaan literasi pada hari senin minggu ke dua digunakan untuk menyimak cerita yang dibacakan oleh guru atau siswa. Apabila siswa yang mendapat tugas membacakan sebuah cerita pendek, kebanyakan siswa kurang percaya diri dan memiliki perasaan malu atau waswas, hal ini dapat dilihat dari cara membaca yang kurang lancar dan beberapa kata ada yang salah membacanya. Semula sering beralasan lupa untuk membawa buku bacaan, tidak punya buku bacaan, ada pula yang membaca buku pelajaran, namun pada minggu minggu berikutnya siswa semua sudah membawa buku bacaan terutama buku cerita. 


\section{d. Respon siswa}

Untuk mendapatkan respon siswa, sekolah menyebarkan kuisener untuk mendapatkan gambaran sejauh mana respon siswa terhadap pelaksanaan literasi lima belas menit sebelum pelajaran dimulai. Kuisener yang disebarkan tidak seluruh siswa mendapatkan kuisener hanya diambil sampel sekitar 50\% dari jumlah semua siswa yang mendapatkan uji rumpang.

Gambaran dari respon siswa seperti pada Gambar 3.2 di bawah ini.

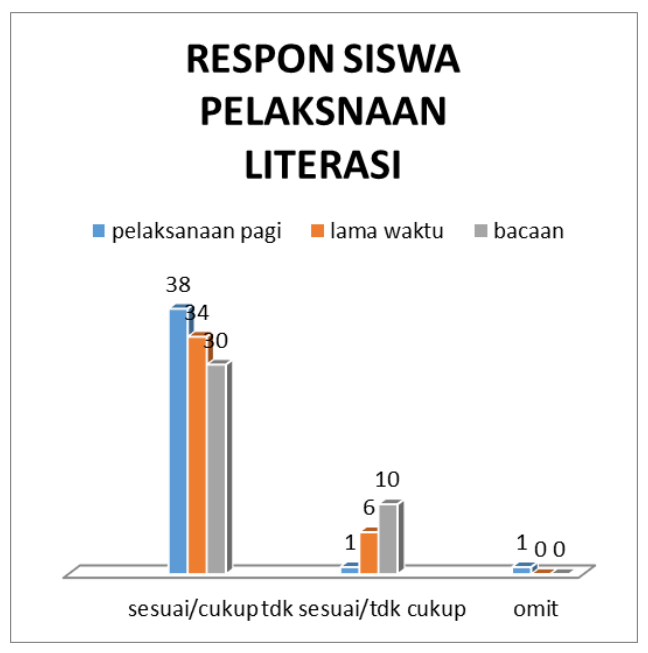

Gambar 2 : Grafik Respon Siswa

Jawaban tidak sesuai pelaksanaan pagi hari, karena terlalu pagi sehingga sering terlambat, apabila terlambat dikenakan sangsi/hukuman. Harapan dari pelaksanaan literasi ini, kami haraapkan yang rajin mendapatkan hadiah sebagai usaha untuk menambah ilmu, di samping itu bisa menulis sebuah cerita atau puisi walaupun sangat sederhana. Usulan dan harapan siswa dalam pelaksanaan literasi sebaiknya membacanya di dalam kelas, dan enam orang menganggap sebaiknya waktu ditambah lima belas menit sehingga total membaca selama 30 menit dan suasana yang tenang. Selain itu buku bacaan novel sebaiknya dari sekolah. Apa bila waktu membaca di halaman sebaiknya alas duduk disediakan untukseluruh siswa. Dampak dari pelaksanaan literasi beberapa yang merasa didapatkan oleh siswa adalah:

1) termotivasi untuk membaca,

2) memupuk kebiasaan membaca,

3) mendapatkan perbendaharaan katakata yang baru,

4) wawasan bertambah

5) lebih dapat memahami suatu bacaan

6) menjadikan contoh untuk adik-adik kelas

\section{DISKUSI HASIL PENELITIAN \\ a. Gambaran Pelaksanaan Literasi}

Menurut Noor Alfu Laila dan Yati dalam penelitian yanag berjudul Pengaruh Penggunaan Media Buku Cerita Terhadap Kemampuan Membaca Siswa Kelas IV Madrasah Ibtidaiyah di Banjarmasin menyimpulkaan bahwa siswa dalam pembelajaran menggunakan media buku cerita hasil belajarnya lebih tinggi dari pada siswa yang pembelajarannya tidak menggunakan media buku cerita. Hal ini mendukung penelitian dampak literasi, dengan demikian siswa akan mudah memahami ide bacaan yang dibaca dan dengan demikian dapat memecahkan masalah yang ada di dalam bacaan. Di samping itu pembelajaran membaca anak didik melalui pembelajaran membaca dapat dikembangkan nilai-nilai moral, kemampuan bernalar dan kreativitasnya( Akhadiah, 1992).

\section{b. Hasil Penangkapan Ide Bacaan}

Bila dilihat hasilnya bahwa penagkapan ide bacaan siswa cukup baik 
dan baik. Berarti siswa telah dapat memahami ide bacaan yang dibacanya, hal ini sesuai pendapat Akhadiah (1992) bahwa dengan membaca siswa memiliki kemampuan bernalar dan memiliki kreativitas yang tinggi. Menurut hasil penelitian Mimi Sri Irfadila (2016) menunjukan bahwa terdapat hubungan antara strategi membaca dengan kemampuan memahami teks bacaan bahasa Indonesia pada mahasiswa prodi pendidikan bahasa dan sastra Indonesia. Hasil penelitian menunjukkan adanya hubungan antara penggunaan strategi dengan kemampuan membaca pemahaman. Apabila strategi membaca pemahaman tinggi, kemampuan membaca pemahaman juga tinggi. Sejalan dengan pelaksanaan literasi setiap pagi merupakan strategi untuk siswa mau membaca bacaan yang mereka senangi. Dengan demikian hasilnya penagnkapan ide bacaan dapat mencapai nilai cukup dan baik, hanya beberapa siswa yang mendapat dibawah rata-rata.

\section{c. Aktivitas siswa}

Pada awalnya siswa merasa enggan untuk membawa buku, namum dengan adanya peraturan dari sekolah siswa akhirnya semuanya menyiapkan buku bacaan yang akan di baca setiap pagi. Hal ini sesuai teori Conditioning adalah suatu bentuk belajar yang memungkinkan organisme memberikan respon terhadap suatu rangsang yang sebelumnya tidak menimbulkan respon itu, atau suatu proses untuk mengintroduksi berbagai reflek menjadi sebuah tingkah laku. Jadi classical conditioning sebagai pembentuk tingkah laku melalui proses persyaratan (conditioning process). Dan Pavlov beranggapan bahwa tingkah laku organisme dapat dibentuk melalui pengaturan dan manipulasi lingkungan (dalam Titin Nurhidayati,2012). Dengan adanya kondisi yang dibuat maka siswa dengan sendirinya membawa buku-buku yang dibutuhkan untuk kepentingan literasi.

\section{Respon siswa}

Pelaksnaan literasi yang dilakukan setiap pagi berdampak sangat positif hampir sampel yang diambil secara acak pelaksanaan literasi sangat sesuai untuk pertumbuhan kognitif dan afeksi siswa. Karena berbagai jawaban mengatakan mereka termotivasi untuk lebih maju dengan bacaan yang mereka baca. Di samping itu mereka mengatakan mendapatkan wawasan yang lebih dari pada sebelumnya, hal ini sesuai penelitian Arfiyani ARP tentang manfaat membaca. Selain dampak literasi mereka memiliki afeksi lebih dari itu untuk memberikan contoh ke pada adik-adik kelasnya.

\section{SIMPULAN DAN SARAN}

Hasil penelitian ini dengan judul "Gambaran Pelaksanaan Literasi dan Penangkapan Ide Bacaan SMP Labschool Unesa Ketintang Surabaya" dapat disimpulkan bahwa pelaksanaan literasi pengaruhnya aktivitas sangat positif, respon sangat baik dan penangkapan ide bacaannya baik.

Sebaiknya waktu membaca duduk di paving yang mereka rasakan kurang nyaman berarti perlunya tempat duduk yang sesuai keadaan mereka. Sekolah menyediakan bacaan yang beraneka ragam agar siswa tidak jenuh bacaan ituitu saja 


\section{DAFTAR PUSTAKA}

Akhadiah, S,.(1992). Bahasa Indonesia III. Jakarta: Departemen P\&rK

Atar, Semi N, 1989, Rancangan Pengajaran Bahasa dan Sastra Indonesia, Angkasa Bandung

Anonim. Teknik Pengajaran

Keterampilan Berbicara. http//www.keterampilan berbicara. Com.(diaksess pada tanggal 20 November 2012 jam 13.25).

Arfyani Rani Anggun P.N., Minat, Motif, Tujuan, Manfaat Membaca Teenlit, dan Peran Perpustakaan, Studi Kasus Mahasiswa Jurusan Sastra Indonesia Pengguna Perpustakaan Fakultas Ilmu Budaya Universitas Diponegoro Semarang

Burhan, Nurgiyantoro, 2004, Penilaian Pembelajaran Sastra Berbasis Kompetensi, FBS Universitas Negeri Yogyakarta

Harjasujana, A.S. (1996). Membaca 2. Jakarta: Depdikbud.

Harjasujana, A.S. dan Mulyati Y. 1997. Bahan Ajar Membaca dan Keterbacaan" dalam Membaca 2. Jakarta: Ditjen Dikdasmen.

Muslich, Masnur dan Oka, I Gusti Ngurah. 2010. Perencanaan Bahasa pada Era Globalisasi. Jakarta: Bumi Aksara.

Mimi, Sri Irfadila, 2012, Hubungan Strategi Membaca Dengan Kemampuan Memahami Teks Bacaan Bahasa Indonesia Mahasiswa, Prodi Pendidikan Bahasa dan Sastra Indonesia FKIP UMSB Padang Panjang, Pendidikan Bahasa dan Sastra Indonesia, FKIP UMSB
Pranowo. 1996. Analisis Pengajaran Bahasa. Yogyakarta: Gadjah Mada University Press.

Semi, Atar. 1993. Metode Penelitian Sastra. Bandung: Angkasa.

Tampubolon. 1999., Kemampuan Membaca Teknik Membaca Efektif dan Efisien. Bandung: CV Angkasa.

Kridalaksana, Harimurti. 1984. Kamus Linguistik. Jakrta: Gramedia

Lubis, A Hamid Hasan, 1991, Analisis Wacana Pragmatik, Bandung, Penerbit Angkasa.

Sadtono (1982: 2), Antologi Pengajaran Bahasa Asing Khususnya Bahasa Inggris, Jakarta Depdikbud

Tarigan, Henry Guntur. 1986. Berbicara sebagai suatu keterampilan berbahasa Bandung: angkasa.

Tarigan, Dj. (1995). Metodik Khusus Pengajaran Bahasa Indonesia di Sekolah Dasar. Bandung:Theme 76.

Tarigan, Henry Guntur. 1987. Teknik Pengajaran Ketrampilan Berbahasa. Bandung :Angkasa.

Titin Nurhidayati, 2012, Implementasi Teori Belajar Ivan Petrovich Pavlov (Classical Conditioning) Dalam Pendidikan, Jurnal Falasifa. Vol. 3, No. 1 Maret 2012

Taylor, Wilson. (1953). Cloze procedure: A New Tool for Measuring Readability. Journalism Quarterly, Canada, 30, 415-433.

Widyamartaya, A. (1992). Seni ,Menuangkan Gagasan. Cetakan Kedua. Yogyakarta: Kanisius.

Zainudin.1992. Materi Pokok Bahasa dan Sastra Indonesia. Jakarta: Rineka Cipta. 